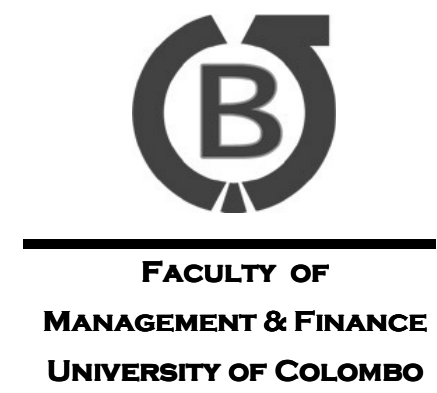

Colombo Business Journal

Vol. 07, No. 02, December, 2016
International Journal of Theory \& Practice

\title{
Editorial: Trends and Issues in Hospitality and Tourism
}

\author{
Maduka Udunuwara ${ }^{a}$, Dale Sanders ${ }^{b}$ \\ ${ }^{a}$ Department of Marketing, University of Colombo, Sri Lanka \\ ${ }^{b}$ School of Business, Edith Cowan University, Australia
}

Tourism is one of the most important and competitive economic sectors in the world. According to United Nations World Tourism Organisation (UNWTO) (2016), the tourism industry contributes nine percent of the world's GDP, provides one out of eleven jobs, and accounts for 1.5 trillion US dollars in exports. The UNWTO projects continued growth in the number of international tourists rising to 1.8 billion in 2030, which would be an increase of 3.3 percent from compared to 2010 . The UNWTO (2015) also predicts a 4.4 per cent annual rise in arrivals to emerging destinations which included Sri Lanka which is twice the rate of the percentage in advanced economies (2.2 percent a year). In addition, the market share of emerging economies will increase and is expected to reach 57 percent by 2030, equivalent to over 1 billion international tourist arrivals.

Sri Lanka is an emerging destination that has experienced a significant growth in tourist arrivals recently with tourist arrivals for the first nine months of 2015 compared to the corresponding period of 2014 increasing by 17 percent (Sri Lanka Tourism Development Authority, 2015). The industry's contribution to employment in Sri Lanka has also recorded an exponential growth in $2014(129,790)$ compared to $2012(67,862)$. The growth of the tourism industry is also evident in the large number of investments in uplifting tourist attractions, encouraging foreign hotels and resorts such as Shangari-la and Marriott. The government has also invested extensively in infrastructure developments that will further facilitate growth in the tourism sector. The government, private sector and higher education providers have also been active organizing seminars, conferences and summits related to tourism development. Despite all this activity, scientific research on hospitality and tourism is emergent in the Sri Lankan context. Thus this special issue of the Colombo business journal on trends and issues in hospitality and tourism provides a timely contribution to the growth in tourism knowledge.

The four articles in this special issue include one paper on cruise tourism, one on ecotourism and two related to customer relationship management. Samarathunga explores the challenges in cruise tourism in relation to shore excursions by the shore excursion service providers. While Samarathunga has identified a large number of challenges, they have been categorized into three broad areas: 
economic, natural and socio-cultural; demand, supply and infrastructure related and service provider related challenges. This paper demonstrates the importance of overcoming the specific barriers to reach the potential of cruise tourism in Sri Lanka. This study provides a number of clues for the newly established ports such as Hambantota and Trincomalee and to enhance undergoing expansion to accommodate cruise ships.

Although ecotourism has become a popular tourism niche in Sri Lanka, questions have been raised on whether it is solely a marketing strategy. Whilst there are international guidelines for "eco" hotels, there seems to be lack of consistency in practice. The paper of Fernando and Kaluarachchi provides a case study of a rainforest Eco lodge identifying its ecotourism practices and compliance with the accepted international standards. Using the framework of international ecotourism principles of Honey (2008) as the theoretical lens, this study examined the ecotourism practices of RFEL, an ecolodge located in Sinharaja forest reserve, through a qualitative case study approach. While this study identified compliance to eight ecotourism practices of Honey, it also revealed the challenges in complying with international ecotourism standards.

This special issue contains two papers in the area of Customer Relationship Management (CRM) in the hotel industry. This can be considered as a much needed contribution due to limited scholarly discussion on CRM practices, critiques and new insights (Li \& Petrick, 2008, Wu \& Lu, 2012). Although there is rich debate and discussion on different players in tourism, such as destination marketing organisations (Fyall, Callod, \& Edwards, 2003), airlines (Chiang, 2014; Wang, 2004), restaurants (Kim, Lee, \& Yoo, 2006), hotels (Akroush, Dahiyat, Gharaibeh, \& Abu-Lail, 2011; Lo, Stalcup, \& Lee, 2010; Luck \& Lancaster, 2013), and casinos (Prentice \& King, 2011), there is a lack of such discussion regarding CRM practices in the industry. The article by Udunuwara, Sanders and Wilkins explores CRM practices in the hotel sector from the perspective of leisure travellers and their perception on CRM to generate repeat visitation and word of mouth. The qualitative approach of this paper has facilitated an in depth understanding on the CRM practices in the hospitality industry. The article by Kumarapeli, Samarasinghe, and Kuruppu investigates CRM practices towards customer brand engagement from the perspective of the hotel industry. Adopting a quantitative approach, this paper discusses the relationship between CRM and brand engagement and identified a direct positive relationship between the two variables. Further, they investigated the moderation effects of hotel category and hotel size on the CRM and brand engagement.

\section{References}

Akroush, M. N., Dahiyat, S. E., Gharaibeh, H. S., \& Abu-Lail, B. N. (2011). Customer relationship management implementation: An investigation of a scale's generalizability and its relationship with business performance in a developing country context. International Journal of Commerce and Management, 21(2), 158-190.

Chiang, W. Y. (2014). A new procedure of market segmentation for dynamic CRM systems: A case study of airlines in Taiwan. International Journal of Information and Communication Technology, 6(3), 422-430.

Fyall, A., Callod, C., \& Edwards, B. (2003). Relationship marketing: The challange for destinations. Annals of Tourism Research, 30(3), 644-659.

Honey, M. (2008). Ecotourism and sustainable development: Who owns paradise? ( ${ }^{\text {nd }}$ ed.). Washington, DC: Island Press. 
Kim, W. G., Lee, Y. K., \& Yoo, Y. J. (2006). Predictors of relationship quality and relationship outcomes in luxury restaurants. Journal of Hospitality \& Tourism Research, 30(2), 143-169.

Li, X., \& Petrick, J. F. (2008). Tourism Marketing in an era of paradigm shift. Journal of Travel Research, 46, 235-244.

Lo, A. S., Stalcup, L. D., \& Lee, A. (2010). Customer realtionship management for hotels in HongKong. International Journal of Contemporary Hospitality Management, 22(2), 139-159.

Luck, D., \& Lancaster, G. (2013). The significance of CRM to the strategies of hotel companies. Worldwide Hospitality and Tourism Themes, 5(1), 55-66.

Prentice, C., \& King, B. (2011). Relationship marketing in the casino industry. Journal of Vacation Marketing, 17(1), 51-63.

Sri Lanka Tourism Development Authority (2015). 2015 annual statistical report. Retrieved from http://www.sltda.lk/sites/default/files/Tourist_Board_Annual_Report_2015.pdf

United Nations World Tourism Organisation (2016). Annual report 2015. Retrieved from http://cf.cdn.unwto.org/sites/all/files/pdf/annual_report_2015_lr.pdf

Wang, D. (2004). Tourist behaviour and repeat visitation to Hong Kong. Tourism Geographies, 6(1), 99-118.

Wu, S. I., \& Lu, C. L. (2012). The relationship between CRM, RM, and business performance: A case study of the hotel industry in Taiwan. International Journal of Contemporary Hospitality Management, 31, 276-285. 